\title{
The effect of the quality of the military's feeding system on meal service satisfaction and intangible combat power: Focusing on soldiers' behavioral intangible combat power
}

\author{
Sangho Lee*
}

This study analyzed the impact of the quality of the military's feeding system on meal service satisfaction and intangible combat power. This research will provide policy implications for the efficient operation of the military's meal policy and budget.

This study identified the four factors (food quality, hygiene, environment, and operation) related to service quality in the military's feeding system. Soldiers' satisfaction with the quality of meal service was 3.21 regarding quality, 3.54 regarding hygiene, 3.35 regarding environment and 3.70 regarding operation of meal service. Satisfaction was found to be the lowest. The correlation between the quality of meal service, quality of meals and the satisfaction with meal service was .820

(a) (1) This work is licensed under a Creative Commons Attribution 4.0 International License.

* (First Author) Sangho, Lee, Kwangwoon University, Defense Acquisition Program, Ph.D. Candidate (Army Consolidated Logistics School, Principal), leesh43kma@hanmail.net 
for quality, .758 for hygiene, .758 for environment, and .724 for meal service. It has been found that hygiene, environment, and operation-related aspects are important factors for the improvement of meal satisfaction in addition to food quality. The correlation index between the quality of meal service and intangible combat power was found to be .233 in quality, .281 in hygiene, .240 in environment, and .308 in operation of meal service. Although the correlation index between the quality of meal service and intangible combat power was moderate, it had significant effects.

Therefore, the future quality control of the group meal service needs to be managed with a balanced sense of hygiene, environment, and operation as well as quality of meals. To improve behavioral intangible combat power, it is necessary to note that the correlation index in terms of operation, hygiene, and environment is higher than the quality of meals.

Keywords : military's feeding system, service quality, service satisfaction, intangible combat power 


\section{I . 서론}

구글이나 애플과 같은 실리콘벨리의 IT 기업들이 자랑하는 복지혜택 중 하나가 사내식당이다. 호텔 레스토랑에 온 것 같은 시설과 분위기에 음식이 뷔페로 준비되고 채식주의자나 특정 종교인 들을 위한 메뉴는 별도로 준비되어 있다고 한다. 이처럼 세계 최고의 기업이 직원들에게 제공하는 '한 끼 식사'는 먹는 즐거움으로만 끝나는 것이 아니라 '업무성과 극대화' 방법으로 주목받고 있다 (김대희, 2018). 이처럼 군(軍)도 ‘한 끼 식사'를 먹는 즐거움뿐만 아니라 ‘전투력 극대화' 방안으로 연계할 필요가 있다. 군 단체급식은 장병들의 건강관리와 훈련 및 근무를 하는데 필요한 에너지를 제공한다. 그래서 급식 서비스 품질은 병사들의 사기진작과 복무 태도에 영향을 미칠 수 있다. 게다 가 국민소득 수준 향상에 따라 단체급식 환경도 변하고 있어 단체급식장은 단순히 식사를 하는 곳 이 아니라 소통의 공간으로 발전하고 있다(이의경, 2017). 이런 의미에서 우리 군(軍)은 장병들의 급식 만족도를 높이기 위해 지속적으로 급식의 질을 개선하고 있다. 그럼에도 2019년도 국방부의 급식 만족도 조사결과, 3.13점 수준으로 여전히 높지 않은 것으로 나타났다.

따라서 본 연구는 장병들의 급식 만족도를 높이고, 장병들이 군 복무간 행동과 태도에 의해 나타 나는 행태적 무형전투력에 영향을 미치는 급식 서비스 품질 요인을 식별하고자 한다. 이를 위해 본 연구는 서비스 - 마케팅 분야의 연구모델을 활용하여 급식 서비스 품질이 장병들의 급식 만족도 및 무형전투력에 미치는 영향을 실증분석하고, 향후 군 단체 급식 정책 발전에 관한 시사점을 제시하 고자 한다.

\section{ㅍ. 이론적 배경 및 가설 도출}

서비스 품질은 소비자들이 지각하는 성과로 급식 서비스 품질은 Cronin \& Taylor(1992)가 제기 한 SERVPERF(service performance) 모델을 적용하여 측정하였다. 만족도는 고객이 특정 서비스 나 제품 등을 제공받은 후 시간이 지남에 따라 즐겁고 만족한 상태에 도달했는가에 대한 판단으로 기대와 경험 간의 일치 여부에 따라 만족과 불만족으로 평가할 수 있다(Oliver, 1997). 따라서 군 단체급식에 대한 장병들의 만족도는 병영식당에서 제공한 서비스 경험을 바탕으로 병사들이 나타 내는 좋고 나쁨에 대한 평가라고 할 수 있다. 급식 서비스 품질과 만족도에 관련 연구를 살펴보면, $\mathrm{Kim}, \mathrm{Kim}, \& \mathrm{Cha}$, 2012)은 급식 만족도에 영향을 미치는 급식 서비스 품질을 음식의 질, 청결성, 인적서비스 등으로 제시하였다. Park(2015)는 학교급식의 만족도에 영향을 미치는 요인으로 음식 (선호메뉴, 맛, 메뉴의 외양 및 다양성), 위생(식기류의 청결, 음식 위생, 조리사의 청결) 등을 제시 하였다.

Allen \& Bell(1980)은 무형전투력에 대해 직무 태도(만족도, 참여도 등), 부대 특성(동기, 의사소 
통 방식, 참여 태도, 부대 수준 등), 사기, 응집력, 군인 품성 병사 간 유대관계, 리더십 등으로 제시 하였다. 이종현, 김환정, 문광건(2001)은 개인(생물적, 심리적) 요인과 집단(응집력, 부대정신, 자군 정신, 군인정신) 요인, 리더 요인으로 구분하고 있다. Kim \& Park(2020)은 임무 수행 능력(전술, 전 기), 전장 리더십, 전장 군기, 훈련 수준 등으로 제시하였다. 이번 연구에서는 병사들의 행동과 태도 에 의해 나타나는 무형전투력 요소를 고려하여 교육 훈련 의지, 사기, 단결, 규정 준수 의지 등으로 제한하여 연구를 실시하였다.

상기한 급식 서비스 품질과 급식 만족도가 무형전투력에 미치는 관계를 살펴보면, 서비스 품질 과 행동 의도에서 고객만족은 중요한 연결고리로 서비스 품질이 높을수록 만족 수준을 높이게 되 어 서비스 품질에 만족할수록 행동 의도에 긍정적인 영향을 미치는 것으로 나타났다(Brady et al., 2005). 지금까지 대다수의 연구는 민간 단체급식 또는 외식 업체의 급식 서비스 부문을 대상으로 서비스 품질이 고객 만족과 고객 행동에 미치는 영향에 초점을 두고 진행되었다. 또한, 군 분야에서 단체급식 서비스 품질과 군 장병들의 급식 만족도 연구(Choi \& Lee, 2012; Lee, Bae, \& Choi, 2020) 에도 불구하고 무형전투력 전반에 미치는 영향을 포괄한 연구가 부족한 실정이다. 따라서 군 단체 급식에서 지각된 서비스 품질과 만족도, 무형전투력 간 관계를 분석하기 위해 다음과 같이 연구가 설을 설정하였다. 첫째, 군 단체급식 서비스 품질은 급식 만족도에 정 $(+)$ 의 영향을 미칠 것이다. 이 는 기존의 급식 서비스 품질이 급식 만족도에 미친 영향을 분석한 다수의 연구를 적용하였다. 둘째, 군 단체급식 서비스 품질은 무형전투력에 정 $(+)$ 의 영향을 미칠 것이다. 이는 서비스 품질이 고객의 행동 의도에 영향을 미친다는 Brady et al.(2005)의 연구결과를 토대로 장병들의 행동과 태도에 영 향을 미칠 것이라는 가정하였다. 셋째, 급식 만족도와 무형전투력은 관계는 Brady et al.(2005)의 만 족도와 행동의도의 관계를 통해 정 $(+)$ 의 상관관계로 가정하였다. 이런 가정에 기반하여 연구모형을 설정하였다(그림 1).

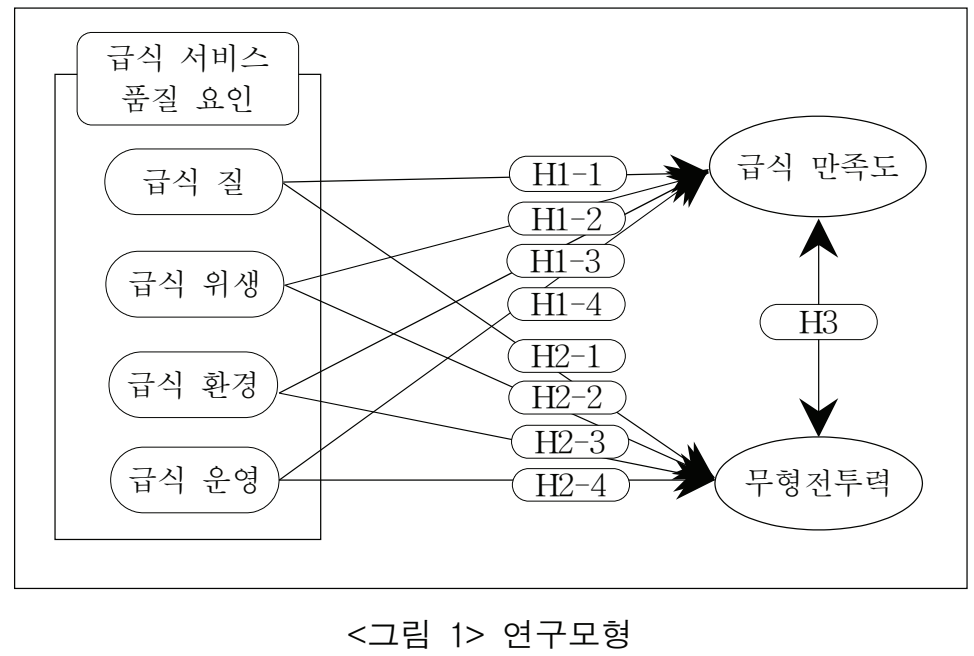




\section{III. 연구 방법}

\section{1 표본 선정과 자료수집}

본 연구는 한 끼 식사 인원이 500명 내외인 육군의 대대급 부대 식당에서 급식을 제공 받고 있는 장병들을 표본집단으로 선정하였다. 부대유형은 전투부대, 전투근무지원부대, 전투지원부대로 분류 하였다. 주특기는 전투병/경계병, 보급병/행정병/운전병으로 분류하여 조사를 실시하였다. 복무 개 월 및 연령, 입대 전 직업 및 주거 형태 등 조사자의 일반적 특성을 파악하여 조사 결과 분석에 활 용하였다. 표본집단의 일반적 특성은 <표 $1>$ 과 같다.

<표 1> 표본집단의 일반적 특성

\begin{tabular}{|c|c|c|c|c|}
\hline \multicolumn{2}{|r|}{ 구분 } & 빈도(명) & 비율(\%) & 평균 \pm 표준편차 \\
\hline \multirow{4}{*}{ 소속부대유형 } & 전투부대 & 765 & 74.1 & \\
\hline & 전투지원부대 & 107 & 10.4 & \\
\hline & 전투근무 지원부대 & 145 & 14.1 & \\
\hline & 기타 & 15 & 1.5 & \\
\hline \multirow{4}{*}{ 주특기 } & 전투병/경계병 & 439 & 42.5 & \\
\hline & 보급병/정비병/운전병 & 315 & 30.5 & \\
\hline & 행정병/의무병 & 88 & 8.5 & \\
\hline & 기타 & 190 & 18.4 & \\
\hline \multirow{4}{*}{ 현 근무기간 } & 2개월 미만 & 14 & 1.4 & \multirow{4}{*}{$10.16 \pm 5.67$} \\
\hline & 2개월-8개월 미만 & 389 & 37.7 & \\
\hline & 8개월-14개월 미만 & 288 & 27.9 & \\
\hline & 14 개월 이상 & 341 & 33.0 & \\
\hline \multirow{4}{*}{ 연령 } & 19세 이하 & 128 & 12.4 & \multirow{4}{*}{$20.78 \pm 1.43$} \\
\hline & 20세 & 362 & 35.1 & \\
\hline & 21세 & 321 & 31.1 & \\
\hline & 22세 이상 & 221 & 21.4 & \\
\hline \multirow{5}{*}{ 입대 전 직업 } & 대학생 & 825 & 79.9 & \\
\hline & 대학진학 준비생 & 28 & 2.7 & \\
\hline & 취업준비생 & 69 & 6.7 & \\
\hline & 회사원 & 52 & 5.0 & \\
\hline & 기타 & 58 & 5.6 & \\
\hline \multirow{6}{*}{ 입대 전 주거형태 } & 부모님과 함께 자가 & 797 & 77.2 & \\
\hline & 원룸/자취 & 134 & 13.0 & \\
\hline & 대학기숙사 & 89 & 8.6 & \\
\hline & 회사숙소 & 7 & .7 & \\
\hline & 기타 & 5 & .5 & \\
\hline & 총계 & 1032 & 100.0 & \\
\hline
\end{tabular}




\section{2 조사 도구}

이 연구를 위한 조사 도구로 설문지와 인터뷰를 실시하였다. 급식 서비스 품질과 만족도를 측정 하기 위해 Lee(2012), Park(2016) 및 Han(2007)의 선행연구를 기초로 설문 항목을 도출하였다. 군 단체급식을 먹는 장병들과의 인터뷰, 전문가 회의를 거쳐 연구목적에 적합하도록 구성하였다. 급식 서비스 품질은 급식 질(7개), 급식 위생(8개), 급식 환경(8개), 급식 운영(6개) 등 4개 요인 29개 항 목으로 구성하였다, 급식 만족도는 급식 질, 급식 위생, 급식 환경, 급식 운영 등 서비스 품질 요인 별 만족도와 전반적인 만족도 5개 항목으로 구성하였다. 무형전투력은 $\operatorname{Kim} \& \operatorname{Park}(2020), \mathrm{Jeon} \&$ $\operatorname{Park}(2015)$, Koo \& Park(2012) 등의 연구를 바탕으로 훈련 의지, 사기, 단결력 강화, 규정 준수 등 4 개 항목으로 구성하였다.

\section{3 자료 분석}

수집된 1,058 부 중, 불성실하게 응답한 26부를 제외한 총 1,032 부를 분석용 자료로 활용하였으며, 통계프로그램인 SPSS와 AMOS를 사용하였으며 분석하였다. 첫째, 빈도분석을 통하여 조사 대상 자의 일반적 특성을 확인하였다. 둘째, 탐색적 요인 및 확인적 요인분석을 실시하여 조사 도구의 타당성과 신뢰도를 검증하였다. 각 요인의 Cronbach's a값을 구하였다. 셋째, 표본집단의 제 변수 의 특성을 알아보기 위하여 평균과 표준편차를 구하였고, 단변량 정규성 검증을 실시하였다. 넷째, 제 변수 간의 상관분석을 실시하였다. 끝으로 가설 검증을 위하여 구조방정식 모형을 통하여 경로 분석을 실시하였다.

\section{$\mathrm{IV}$. 분석결과}

\section{1 측정 도구의 타당성 및 신뢰성 분석}

\subsection{1 탐색적 요인분석 및 신뢰도 분석}

4.1.1.1 외생변수의 탐색적 요인분석

본 연구의 독립변수인 서비스 품질요인 측정 도구의 타당도 분석을 위해 실시한 탐색적 요인분 석 결과는 다음 표 2 와 같다. 즉 요인분석에서 요인적재량이 0.5 이하인 적온 급식, 손 씻기 등 2 개 문항과 취사 요원의 친절성 등 문항의 성격이 다르게 묶인 문항, 수저, 식판, 배식대, 식수대, 식탁 의자 등 위생과 환경 2 개의 요인에 동시에 묶인 4 개 문항 등 총 7 개의 문항을 삭제하였다. 이후 급 식 서비스 품질은 4 개의 요인을 추출하였다. 각 요인의 고유값은 1 이상을 나타내고 있고, 총 분산 
은 71.746\%이었으며, 요인적재량은 모두 0.5 이상으로 나타났다. 또한, $\mathrm{KMO}$ 값이 .958로 매우 좋은 수준을 보였고, Barlett의 구형성 검증 결과는 유의확률이 $\mathrm{p}<.001$ 로 나타나 변수 간 상관관계를 잘 나타내고 있었고, 요인은 적합성과 타당성이 있는 것으로 나타났다. 추출된 4개 요인명은 문항의 성격에 따라 요인 1 ‘급식 위생', 요인 2 ‘급식 질', 요인 3 ‘급식 운영’, 요인 4 ‘급식 환경’으로 명명하 였다. 한편 신뢰도 분석결과, Cronbach's a 값은 급식 위생 .943, 급식의 질 .898, 급식 운영 .855, 급 식 환경 .908로 바람직한 수준으로 나타났다.

<표 2> 외생변수의 탐색적 요인분석 및 신뢰도 분석 결과

\begin{tabular}{|c|c|c|c|c|c|}
\hline 항 목 & 요인 1 & 요인 2 & 요인 3 & 요인 4 & Cronbach's a \\
\hline 위생2. 식탁/의자, 바닥 & .832 & .237 & 2.159 & .227 & \multirow{7}{*}{.943} \\
\hline 위생3. 배식대/식수대, 컵 & .831 & .218 & .193 & .227 & \\
\hline 위생4. 식기소독기, 식판보관함 & .807 & .230 & .263 & .228 & \\
\hline 위생5. 잔반처리, 식기세척장 & .799 & .202 & .209 & .294 & \\
\hline 위생1. 식판, 수저 & .762 & .174 & .217 & .070 & \\
\hline 위생6. 출입문, 창문 & .758 & .259 & .202 & .293 & \\
\hline 위생8. 조리원 복장, 용모 & .592 & .260 & .269 & .286 & \\
\hline 급식 질4. 맛 & .203 & .828 & .162 & .251 & \multirow{6}{*}{.898} \\
\hline 급식 질5. 간 & .277 & .781 & .132 & .227 & \\
\hline 급식 질1. 식사재료 품질 & .262 & .755 & .234 & .188 & \\
\hline 급식 질2. 메뉴 다양성 & .173 & .701 & .278 & .156 & \\
\hline 급식 질6. 식사 량 & .169 & .684 & .234 & .169 & \\
\hline 급식 질7. 건강식 & .302 & .562 & .372 & .165 & \\
\hline 운영2. 영양정보 제공 & .258 & .124 & .746 & .081 & \multirow{5}{*}{.855} \\
\hline 운영1. 공지된 식단표 준수 & .193 & .301 & .697 & .181 & \\
\hline 운영4. 적정한 식사시간 보장 & .192 & .249 & .694 & .243 & \\
\hline 운영5. 주기적인 메뉴 순환 & .275 & .341 & .633 & .247 & \\
\hline 운영3. 배식시간 미지체 & .230 & .262 & .622 & .372 & \\
\hline 환경6. 시설 및 인테리어 & .377 & .293 & .203 & .783 & \multirow{4}{*}{.908} \\
\hline 환경7. 식당 조명 & .375 & .293 & .239 & .774 & \\
\hline 환경5. TV, 오디오 등 비품 & .185 & .263 & .279 & .696 & \\
\hline 환경8. 내부 공간 편리성 & .414 & .235 & .281 & .671 & \\
\hline 고유값 & 5.273 & 4.152 & 3.271 & 3.088 & \\
\hline 분산(\%) & 23.968 & 18.871 & 14.870 & 14.038 & \\
\hline 누적분산(\%) & 23.968 & 42.838 & 57.709 & 71.746 & \\
\hline
\end{tabular}

$\mathrm{KMO}=.958$, Bartlett's Test of Sphericity $=18490.986, d f=231, p<.001$ 


\subsubsection{2 내생변수의 탐색적 요인분석 및 신뢰도 분석}

본 연구의 매개변수와 종속변수인 급식 만족도와 무형전투력 측정 도구와의 타당도 분석을 위해 실시한 탐색적 요인분석 결과는 표 3과 같다. 요인분석에서는 2 개의 요인이 추출되었다. 각 요인의 고유값은 1 이상을 나타내고 있으며, 총 분산은 $84.504 \%$ 이었고, 요인적재량은 모두 0.5 이상으로 나타났다. 또한, $\mathrm{KMO}$ 값이 .960으로 매우 좋은 수준을 보였고, Barlett의 구형성 검증 결과는 유의 확률이 $\mathrm{p}<.001$ 로 나타나고 변수 간의 상관관계를 잘 나타내고 있었으며, 요인은 적합성과 타당성이 있는 것으로 나타났다. 추출된 2개 요인명은 문항의 성격에 따라 요인 1 '무형전투력', 요인 2 '급식 만족'으로 명명하였다. 한편 신뢰도 분석결과, Cronbach's a값은 무형전투력 .950, 급식 만족 .990으 로 바람직한 수준으로 나타났다.

<표 3> 내생변수의 탐색적 요인분석 및 신뢰도 분석 결과

\begin{tabular}{|c|c|c|c|}
\hline 항 목 & 요인 1 & 요인 2 & Cronbach's a \\
\hline 무형11. 편리한 급식환경이 단결력 강화 & .936 & .110 & \multirow{20}{*}{.950} \\
\hline 무형15. 친절한 급식운영이 단결력 강화 & .935 & .128 & \\
\hline 무형10. 편리한 급식환경이 사기 앙양 & .932 & .119 & \\
\hline 무형13. 친절한 급식운영이 훈련의지 강화 & .931 & .131 & \\
\hline 무형12. 편리한 급식환경이 규정준수 유도 & 929 & .129. & \\
\hline 무형14. 친절한 급식운영이 사기 앙양 & 929 & .128. & \\
\hline 무형19. 급식 만족도가 단결력 강화 & .926 & .115 & \\
\hline 무형9. 편리한 급식환경이 훈련의지 강화 & .924 & .115 & \\
\hline 무형16. 친절한 급식운영이 규정준수 유도 & .920 & .136 & \\
\hline 무형7. 청결한 급식위생이 단결력 강화 & .918 & .115 & \\
\hline 무형20. 급식 만족도가 규정준수 유도 & .913 & .119 & \\
\hline 무형6. 청결한 급식위생이 사기 앙양 & .911 & .124 & \\
\hline 무형8. 청결한 급식위생이 규정준수 유도 & .910 & .139 & \\
\hline 무형17. 편리한 급식환경이 규정준수 유도 & .908 & .105 & \\
\hline 무형18. 급식 만족도가 사기 앙양 & .908 & .105 & \\
\hline 무형5. 청결한 급식위생이 훈련의지 강화 & .905 & .118 & \\
\hline 무형3. 좋은 급식질이 단결력 강화 & .890 & .117 & \\
\hline 무형4. 좋은 급식질이 규정준수 유도 & .888 & .117 & \\
\hline 무형2. 좋은 급식질이 사기 앙양 & .883 & .112 & \\
\hline 무형1. 좋은 급식질이 훈련의지 강화 & .847 & .120 & \\
\hline 만족도5. 급식 전반에 만족 & .093 & .937 & \multirow{5}{*}{.990} \\
\hline 만족도4. 급식 운영에 만족 & .124 & .923 & \\
\hline 만족도3. 급식 환경에 만족 & .151 & .920 & \\
\hline 만족도1. 급식 질에 만족 & .090 & .882 & \\
\hline 만족도2. 급식 위생에 만족 & .139 & .869 & \\
\hline
\end{tabular}




\begin{tabular}{c|c|c|}
\hline 고유값 & 16.727 & 4.399 \\
\cline { 1 - 2 } 분산(\%) & 66.910 & 17.594 \\
\hline 누적분산(\%) & 66.910 & 84.504 \\
\hline $\mathrm{KMO}=.960$, Bartlett's Test of Sphericity $=48309.296, d f=300, p<.001$ \\
\hline
\end{tabular}

\subsection{2 확인적 요인분석}

4.1.2.1 외생변수의 확인적 요인분석

4.1.2.1.1 모형의 적합도 검증

탐색적 요인분석을 통해 선정된 측정항목에 대한 타당성 검증은 확인적 요인분석을 실시하여 개 념 타당성을 살펴보았다. 본 연구에서 설정한 독립변수인 급식 서비스 품질 요소 측정모형을 구조 방정식 모형의 적합도 판단기준에 따라 검증하였다(그림 2, 표 4).

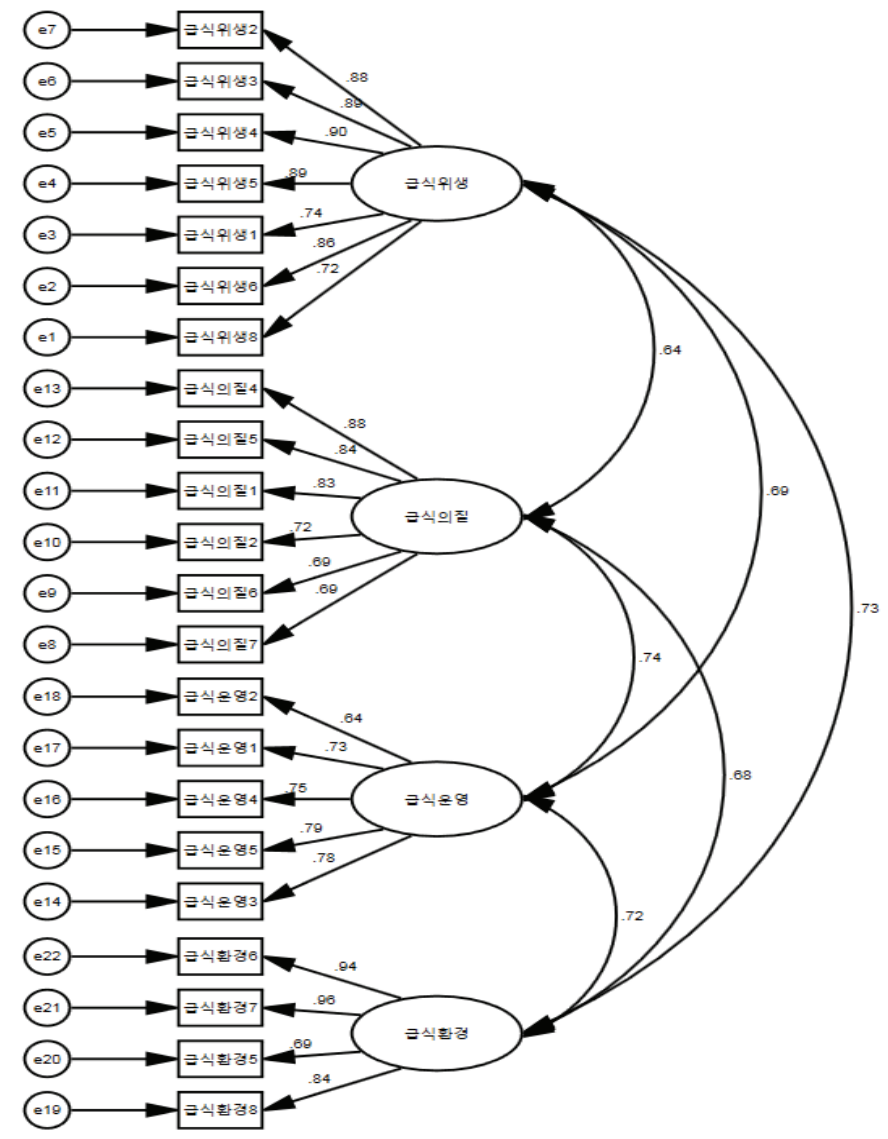

<그림 2> 외생변수 측정모형 
<표 4> 외생변수 측정모형의 적합도 검증

\begin{tabular}{c|c|c|c|c|c|c}
\hline 구 분 & $x^{2}$ & $\mathrm{RMR}$ & $\mathrm{GFI}$ & $\mathrm{TLI}$ & $\mathrm{CFI}$ & RMSEA \\
\hline \hline 기준 & $p>.05$ & .05 이하 & .80 이상 & .90 이상 & .90 이상 & .08 이하 \\
\hline 측정모형 & $\begin{array}{c}1140.165 \\
p=.000\end{array}$ & .048 & .906 & .942 & .949 & .067 \\
\hline
\end{tabular}

위의 표 4 와 같이 측정모형의 확인적 요인분석 결과 $x^{2}$ 값이 기준값을 충족하지 못하였으나, $\mathrm{RMR}=.048, \mathrm{GFI}=.906, \mathrm{TLI}=.942, \mathrm{CFI}=.949, \mathrm{RMSEA}=.067$ 로 적합도 기준을 만족하였다. 적합도는 절대적 기준이 아니므로 다른 지표들과 통합하여 판단할 수 있다(Kim. G., 2017). 따라서 $x^{2}$ 값을 제 외한 다른 모든 지표들이 모두 기준값을 충족하므로 본 모형은 적합하다고 할 수 있다.

\subsubsection{2 내생변수 측정 도구의 확인적 요인분석}

\subsubsection{1 모형의 적합도 검증}

탐색적 요인분석을 통해 선정된 측정항목에 대하여 타당성 검증을 위해 확인적 요인분석을 실시 하여 개념 타당성을 살펴보았다. 검증 결과, 모형적합도가 기준을 충족하지 못하여 수정지수 (Modification Index)를 사용하여 모형 적합도를 낮추는 문항을 제거하였으며, 최종 검증 결과는 그 림 3 과 표 5 와 같다.

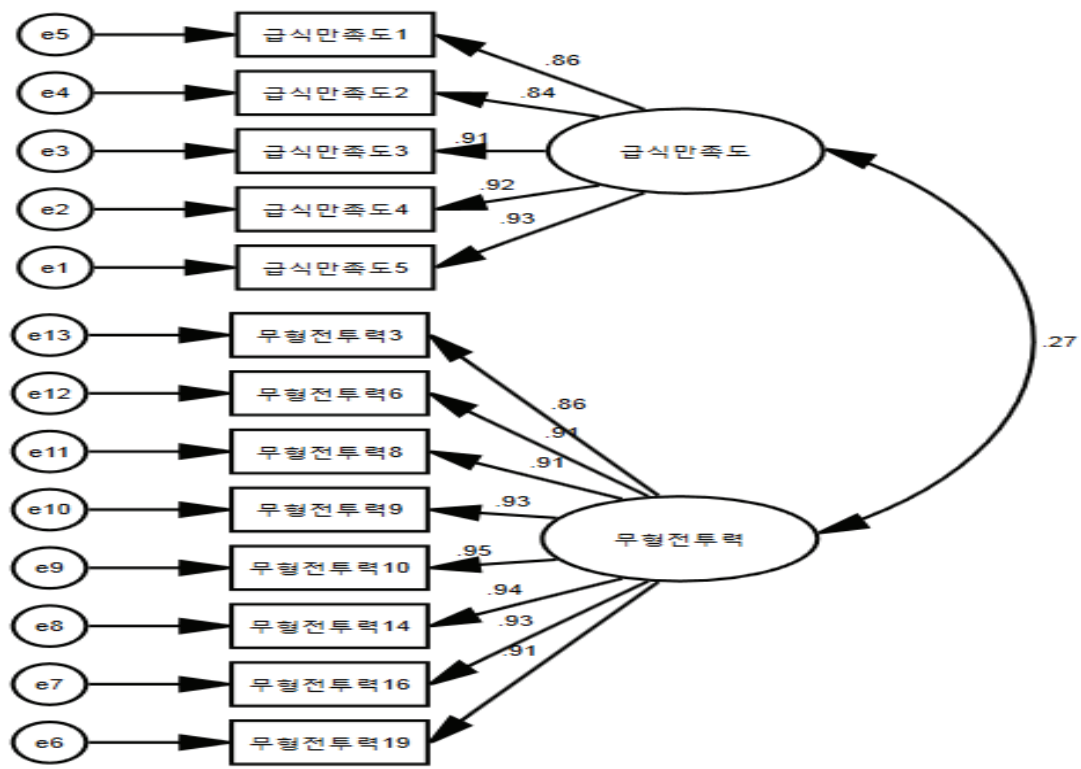

<그림 3> 내생변수 측정모형

주) 숫자는 표준화 계수 
<표 5> 내생변수 측정 모형의 적합도 검증

\begin{tabular}{c|c|c|c|c|c|c}
\hline 구 분 & $x^{2}$ & RMR & GFI & TLI & CFI & RMSEA \\
\hline \hline 기준 & $\mathrm{p}>.05$ & .05 이하 & .8 이상 & .9 이상 & .9 이상 & .08 이하 \\
\hline 측정모형 & $\begin{array}{c}1259.642 \\
\mathrm{p}=.000\end{array}$ & .025 & .845 & .920 & .934 & .135 \\
\hline
\end{tabular}

표 5에서 수정 측정모형의 확인적 요인분석 결과, $x^{2}$ 값과 RMSEA값이 기준값을 충족하지 못하 였으나 $\mathrm{RMR}=.025, \mathrm{GFI}=.845, \mathrm{TLI}=.920, \mathrm{CFI}=.934$ 로 적합도를 만족하였다. 적합도는 절대적 기준이 아니므로 다른 지표들과 통합하여 판단할 수 있다(Kim. G., 2017). 따라서 $x^{2}$ 값을 제외한 다른 모든 지표들이 모두 기준값을 충족하므로 본 모형은 적합하다고 할 수 있다.

\section{2. 기초통계량 분석}

\subsection{1 정규성 검증 및 연구 변인 특성}

본 연구에서는 측정 도구의 평균 및 표준편차를 구하여, 최대우도법(ML: Maximum Likelihood) 을 사용하여 단변량 정규성 검증을 위해 왜도와 첨도 값을 살펴보았다. 변수들의 왜도와 첨도 절대 값을 확인한 결과, 왜도의 절대값 2 , 첨도의 절대값 7 을 초과하지 않는 것으로 나타나 단변량 정규 분포성을 만족하는 것으로 확인되었다(표 6). 한편, 요인별로 급식 서비스 품질 요소의 급식 질 평 균 3.21점, 급식 위생 평균 3.54점, 급식 환경 평균 3.35점, 급식 운영 평균 3.70점으로 급식 운영이 가장 높았으며, 급식의 질이 가장 낮았다. 한편 급식 만족도는 평균 3.33점으로 나타났으며, 무형전 투력은 평균 4.15점으로 높게 나타났다.

<표 6> 관측변수의 기술 통계량

\begin{tabular}{c|c|c|c|c|c}
\hline 구 분 & $\mathrm{N}$ & 평균 & 표준편차 & 왜도 & 첨도 \\
\hline \hline 급식 질 & 1032 & 3.21 & .87 & .123 & -.106 \\
\hline 급식 위생 & 1032 & 3.54 & .88 & -.223 & -.127 \\
\hline 급식 환경 & 1032 & 3.35 & 1.01 & -.106 & -.424 \\
\hline 급식 운영 & 1032 & 3.70 & .78 & -.102 & -.192 \\
\hline 급식 만족 & 1032 & 3.33 & .98 & -.187 & -.189 \\
\hline 무형전투력 & 1032 & 4.15 & .88 & -.958 & .803 \\
\hline
\end{tabular}

\subsection{2 측정변수 간 상관관계}

이 연구에서 측정 변수들 간의 상호연관성을 확인하기 위하여 상관분석을 실시하였으며 결과는 표 7과 같다. 분석결과, 모든 변수 간의 상관관계가 .223 . 820 의 정적 상관관계로 나타났으며, .90 
이상의 상관계수를 보이는 측정변수가 없어 자기상관 변수는 나타나지 않았다. 급식의 질은 급식 만족 $(\mathrm{r}=.820, \mathrm{p}<.001)$ 과 높은 정 $(+)$ 의 상관관계를 보였으며, 무형전투력 $(\mathrm{r}=.223, \mathrm{p}<.001)$ 과 정 $(+)$ 의 상관관계를 보였다. 급식 위생은 급식 만족 $(\mathrm{r}=.758, \mathrm{p}<.001)$ 과 높은 정 $(+)$ 의 상관관계를 보였으며, 무형전투력 $(\mathrm{r}=.281, \mathrm{p}<.001)$ 과도 정 $(+)$ 의 상관관계를 보였다. 급식 환경은 급식 만족 $(\mathrm{r}=.676, \mathrm{p}<.001)$ 과 정 $(+)$ 의 상관관계를 보였으며, 무형전투력 $(\mathrm{r}=.240, \mathrm{p}<.001)$ 과도 정 $(+)$ 의 상관관계를 보였다. 급식 운영은 급식 만족 $(\mathrm{r}=.724, \mathrm{p}<.001)$ 과 높은 정 $(+)$ 의 상관관계를 보였으며, 무형전투력 $(\mathrm{r}=.308, \mathrm{p}<.001)$ 과도 정 $(+)$ 의 상관관계를 보였다. 급식 만족은 무형전투력 $(\mathrm{r}=.261, \mathrm{p}<.001)$ 과 정 $(+)$ 의 상관관계를 보 였다.

<표 7> 측정변수 간 상관관계

\begin{tabular}{c|c|c|c|c|c}
\hline 구 분 & 급식 질 & 급식위생 & 급식환경 & 급식운영 & 급식만족 \\
\hline \hline 급식의 질 & - & & & & \\
\hline 급식 위생 & $.611^{* * *}$ & - & & & \\
\hline 급식 환경 & $.651^{* * *}$ & $.700^{* * *}$ & - & & \\
\hline 급식 운영 & $.669^{* * *}$ & $.631^{* * *}$ & $.676^{* * *}$ & - & \\
\hline 급식 만족 & $.820^{* * *}$ & $.758^{* * *}$ & $.758^{* * *}$ & $.724^{* * *}$ & - \\
\hline 무형전투력 & $.223^{* * *}$ & $.281^{* * *}$ & $.240^{* * *}$ & $.308^{* * *}$ & $.261^{* * *}$ \\
\hline **** $\mathrm{p}<.001$
\end{tabular}

\section{3 가설 검증}

본 연구모형에 대한 적합도를 검증한 결과, $x^{2}$ 값이 기준값을 충족하지 못하였으나, $\mathrm{RMR}=.045$, $\mathrm{GFI}=.831, \mathrm{TLI}=.919, \mathrm{CFI}=.926, \mathrm{RMSEA}=.072$ 로 나타나 적합도 기준을 충족하여 본 모형은 적합도 를 만족한 것으로 볼 수 있다(표 8). 본 연구모형의 경로분석 결과는 그림 4와 표 9에 제시하였다.

<표 8> 연구모형의 적합도 검증

\begin{tabular}{c|c|c|c|c|c|c}
\hline 구 분 & $x^{2}$ & $\mathrm{RMR}$ & $\mathrm{GFI}$ & $\mathrm{TLI}$ & $\mathrm{CFI}$ & RMSEA \\
\hline \hline 기 준 & $\mathrm{p}>.05$ & .05 이하 & .8 이상 & .9 이상 & .9 이상 & .08 이하 \\
\hline 측정모형 & $\begin{array}{c}3433.199 \\
\mathrm{p}=.000\end{array}$ & .045 & .831 & .919 & .926 & .072 \\
\hline
\end{tabular}




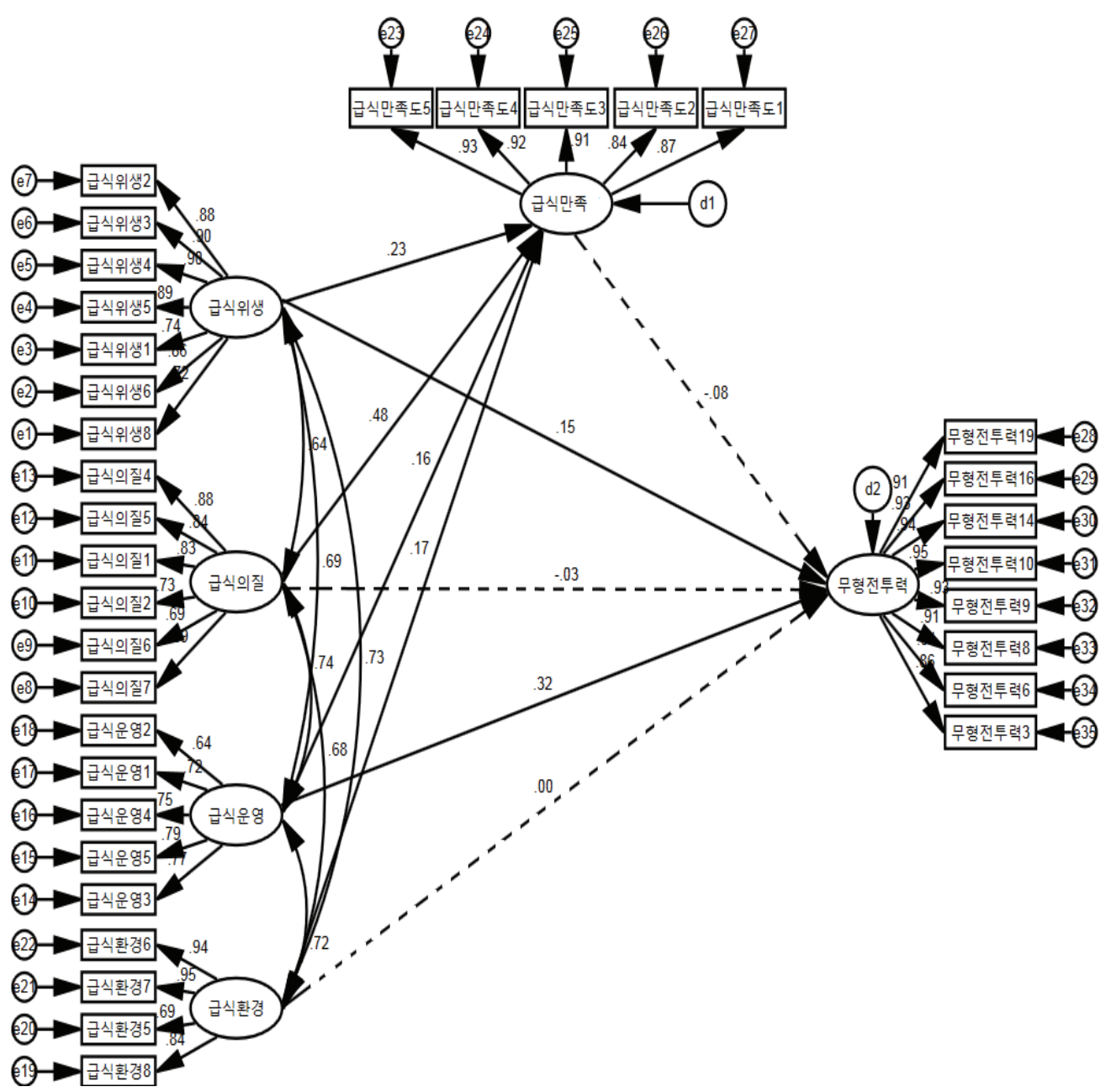

<그림 4> 연구모형의 경로분석

* 숫자는 표준화 계수

실선은 유의한 영향을 미치는 경로, 점선은 유의한 영향을 미치지 않는 경로임

<표 9> 연구모형의 경로계수

\begin{tabular}{|c|c|c|c|c|c|c|}
\hline \multicolumn{2}{|c|}{ 경 로 } & 표준화 Estimte & 비표준화 Estimte & S.E. & C.R. & $\mathrm{p}$ \\
\hline 급식만족 & $\leftarrow$ 급식위생 & .231 & .316 & (.035 & 9.103 & $.000^{* * * *}$ \\
\hline 급식만족 & $\leftarrow$ 급식의질 & .483 & .766 & .049 & 15.702 & $.000^{* * * *}$ \\
\hline 급식만족 & $\leftarrow$ 급식운영 & .163 & .193 & .036 & 5.402 & $.000^{* * *}$ \\
\hline 급식만족 & $\leftarrow$ 급식환경 & .174 & .190 & .029 & 6.653 & $.000^{* * *}$ \\
\hline 무형전투력 & $\leftarrow$ 급식만족 & -.083 & -.072 & .090 & -.796 & .426 \\
\hline 무형전투력 & $\leftarrow$ 급식위생 & .146 & .173 & .067 & 2.593 & $.010^{*}$ \\
\hline
\end{tabular}




\begin{tabular}{|c|c|c|c|c|c|c|}
\hline \multicolumn{2}{|l|}{ 경 로 } & 표준화 Estimte & 비표준화 Estimte & S.E. & C.R. & $\mathrm{p}$ \\
\hline 무형전투력 & $\leftarrow$ 급식의질 & -.026 & -.036 & .106 & -.341 & .733 \\
\hline 무형전투력 & $\leftarrow$ 급식운영 & .318 & .327 & .068 & 4.810 & $.000^{* * *}$ \\
\hline 무형전투력 & $\leftarrow$ 급식환경 & .003 & .003 & .054 & .057 & .954 \\
\hline 만족도5(전반적 만족) & $\leftarrow$ 급식만족 & .927 & 1 & & & \\
\hline 만족도4(급식 운영) & $\leftarrow$ 급식만족 & .918 & .972 & .018 & 52.726 & $.000^{* * *}$ \\
\hline 만족도3(급식 환경) & $\leftarrow$ 급식만족 & .908 & .971 & .019 & 50.911 & $.000^{* * *}$ \\
\hline 만족도2(급식 위생) & $\leftarrow$ 급식만족 & .842 & .898 & .022 & 41.318 & $.000^{* * *}$ \\
\hline 만족도1(급식 질) & $\leftarrow$ 급식만족 & .869 & .987 & .022 & 44.757 & $.000^{* * *}$ \\
\hline 무형19(만족도-단결력) & $\leftarrow$ 무형전투력 & .913 & 1 & & & \\
\hline 무형16(운영-규정준수) & $\leftarrow$ 무형전투력 & .929 & 1.037 & .02 & 52.975 & $.000^{* * *}$ \\
\hline 무형14(운영-사기) & $\leftarrow$ 무형전투력 & .945 & 1.007 & .018 & 55.925 & $.000^{* * *}$ \\
\hline 무형10(환경-사기) & $\leftarrow$ 무형전투력 & .949 & 1.011 & .018 & 56.736 & $.000^{* * *}$ \\
\hline 무형9(환경-훈련) & $\leftarrow$ 무형전투력 & .933 & 1.017 & .019 & 53.685 & $.000^{* * *}$ \\
\hline 무형8(위생-규정) & $\leftarrow$ 무형전투력 & .911 & 1.018 & .020 & 49.788 & $.000^{* * *}$ \\
\hline 무형6(위생-사기) & $\leftarrow$ 무형전투력 & .908 & .996 & .020 & 49.304 & $.000^{* * *}$ \\
\hline 무형3(급식 질-단결력) & $\leftarrow$ 무형전투력 & .865 & .982 & .023 & 43.248 & $.000^{* * *}$ \\
\hline 위생8(조리원 복장, 용모) & $\leftarrow$ 급식위생 & .717 & 1 & & & \\
\hline 위생6(출입문, 창문) & $\leftarrow$ 급식위생 & .860 & 1.210 & .044 & 27.489 & $.000^{* * *}$ \\
\hline 위생1(식판, 수저) & $\leftarrow$ 급식위생 & .739 & 1.096 & .047 & 23.499 & $.000^{* * *}$ \\
\hline 위생5(잔반, 식기세척) & $\leftarrow$ 급식위생 & .890 & 1.304 & .046 & 28.465 & $.000^{* * *}$ \\
\hline 위생4(식기 소독, 보관함) & $\leftarrow$ 급식위생 & .896 & 1.208 & .042 & 28.664 & $.000^{* * *}$ \\
\hline 위생3(배식대, 식수대, 컵) & $\leftarrow$ 급식위생 & .896 & 1.237 & .043 & 28.659 & $.000^{* * *}$ \\
\hline 위생2(식탁/의자, 바닥) & $\leftarrow$ 급식위생 & .882 & 1.245 & .044 & 28.218 & $.000^{* * *}$ \\
\hline 급식 질7(건강식 제공) & $\leftarrow$ 급식의질 & .692 & 1 & & & \\
\hline 급식 질6(식사 량) & $\leftarrow$ 급식의질 & 691 & 1.292 & .062 & 20.890 & $.000^{* * *}$ \\
\hline 급식 질2(메뉴 다양성) & $\leftarrow$ 급식의질 & .725 & 1.268 & .058 & 21.858 & $.000^{* * *}$ \\
\hline 급식 질1(식사재료 품질) & $\leftarrow$ 급식의질 & .828 & 1.352 & .055 & 24.722 & $.000^{* * *}$ \\
\hline 급식 질5(음식의 간) & $\leftarrow$ 급식의질 & .837 & 1.443 & .058 & 24.988 & $.000^{* * *}$ \\
\hline 급식 질4(음식의 맛) & $\leftarrow$ 급식의질 & .880 & 1.539 & .059 & 26.130 & $.000^{* * *}$ \\
\hline 운영3(배식시간 지체) & $\leftarrow$ 급식운영 & .770 & 1 & & & \\
\hline 운영5(메뉴 순환) & $\leftarrow$ 급식운영 & .793 & .931 & .036 & 26.033 & $.000^{* * *}$ \\
\hline 운영4(적정한 식사시간) & $\leftarrow$ 급식운영 & .751 & .810 & .033 & 24.502 & $.000^{* * * *}$ \\
\hline 운영1(식단표 준수) & $\leftarrow$ 급식운영 & .724 & .856 & .036 & 23.491 & $.000^{* * *}$ \\
\hline 운영2(영양정보 제공) & $\leftarrow$ 급식운영 & .640 & .715 & .035 & 20.466 & $.000^{* * *}$ \\
\hline 환경8(식당내부 공간) & $\leftarrow$ 급식환경 & .837 & 1 & & & \\
\hline 환경5(TV, 오디오 이용) & $\leftarrow$ 급식환경 & .694 & .979 & .038 & 25.560 & $.000^{* * *}$ \\
\hline 환경7(조명) & $\leftarrow$ 급식환경 & .954 & 1.121 & .026 & 42.622 & $.000^{* * *}$ \\
\hline 환경6(인테리어) & $\leftarrow$ 급식환경 & .944 & 1.151 & .028 & 41.844 & $.000^{* * *}$ \\
\hline
\end{tabular}

$* \mathrm{p}<.05, * * \mathrm{p}<.01, * * * \mathrm{p}<001$ 


\subsection{1 가설 검증 결과}

4.3.1.1 가설 1 의 검증 : 급식 서비스 품질이 급식 만족에 미치는 영향

표 9에서 급식의 질이 급식 만족에 이르는 경로를 살펴보면, C.R. 값 15.702 , 유의수준 $p=.000$ 으로, 급식의 질은 급식 만족에 정(+)의 영향을 미치는 것으로 나타났으며, 급식 위생이 급식 만족에 이르 는 경로에서 C.R. 값 9.103, 유의수준 $p=.000$ 으로, 급식 위생은 급식 만족에 정(+)의 영향을 미치는 것 으로 나타났다. 급식 환경이 급식 만족에 이르는 경로에서 C.R.값 6.653 , 유의수준 $p=.000$ 으로, 급식 환경은 급식 만족에 정(+)의 영향을 미치는 것으로 나타났으며, 급식 운영이 급식 만족에 이르는 경 로에서 C.R.값 5.402, 유의수준 $p=.000$ 으로, 급식 운영은 급식 만족에 정 $(+)$ 의 영향을 미치는 것으로 나타났다. 따라서 가설 1-1 '급식의 질은 급식 만족에 정(+)의 영향을 미칠 것이다'와 가설 1-2 '급식 위생은 급식 만족에 정(+)의 영향을 미칠 것이다'. 가설 1-3 ‘급식 환경은 급식 만족에 정(+)의 영향을 미칠 것이다', 가설 1-4 '급식 운영은 급식 만족에 정(+)의 영향을 미칠 것이다'는 모두 채택되었다.

\subsubsection{2 가설 2 의 검증 : 급식 서비스 품질이 무형전투력에 미치는 영향}

급식 위생이 무형전투력에 이르는 경로에서 C.R.값 2.593, 유의수준 $p=.010$ 으로 급식 위생은 무 형전투력에 정(+)의 영향을 미치는 것으로 나타났으며, 급식 운영이 무형전투력에 이르는 경로에서 C.R. 값 4.810, 유의수준 $p=.000$ 으로, 급식 운영은 무형전투력에 정 $(+)$ 의 영향을 미치는 것으로 나타 났다. 그러나 급식의 질과 급식 환경이 무형전투력에 이르는 경로에서는 유의미한 영향을 미치지 않는 것으로 나타났다. 따라서 가설 2-2 '급식 위생은 무형전투력에 정(+)의 영향을 미칠 것이다'와 가설 2-4 '급식 운영이 무형전투력에 정(+)의 영향을 미칠 것이다'는 채택되었으나, 가설 2-1 '급식 의 질은 무형전투력에 정(+)의 영향을 미칠 것이다'와 가설 2-3 '급식 환경은 무형전투력에 정(+)의 영향을 미칠 것이다'는 기각되었다.

\subsubsection{3 가설 3 의 검증 : 급식 만족과 무형전투력의 상관관계}

급식 만족과 무형전투력의 관계에서 유의미한 영향은 미치지 않은 것으로 나타났다. 그러나 두 독립 변수 간의 상호관련성 정도에 관한 상관관계 분석결과, 급식 만족과 무형전투력 $(\mathrm{r}=.261$, $p<.001$ )은 정 $(+)$ 의 상관관계가 나타났다(표-7). 따라서 가설 3 '급식 만족과 무형전투력에 정 $(+)$ 의 상관관계를 보일 것이다'는 채택되었다.

\section{V. 논 의}

본 연구는 군 단체급식의 서비스 품질 요인이 급식만족도와 행태적 무형전투력에 미치는 영향관 계를 밝히는 데 목적을 두고 있다. 이를 위해 단체급식 서비스 품질이 급식만족도 및 무형전투력에 
미치는 영향을 통계적 검증을 토대로 검증하였다.

첫째, 탐색적 요인 분석 및 신뢰도 분석결과 요인은 적합성과 타당성이 있었으며 신뢰도 분석결 과 Cronbach's a 값이 바람직한 수준으로 나타났다. 단체급식 서비스 품질은 급식의 질, 위생, 환경, 운영 등 4 개 차원으로 구성됨을 확인할 수 있었다. 각 세부 요인별로 살펴보면, 급식의 질에서 요인 적재량이 높았던 문항은 음식 맛, 간, 우수한 식재료, 메뉴의 다양성, 적절한 식사량, 건강식 순서로 나타났다. 음식 질 향상을 위해서는 맛이 최우선적으로 관리되어야 할 요소이며 이는 입대 전 장병 들이 외식 식당 선택시 최우선적으로 고려했던 요인과도 일치한다. 급식 위생에서 요인적재량이 높 았던 문항은 식탁과 바닥의 청결 상태, 배식대 및 식수대, 물컵 청결, 식기 소독기, 식판 보관함, 잔 반 처리 및 식기세척장, 식판 및 수저, 식당 출입문과 창문, 조리원 복장 및 용모 순으로 나타났다. 위생요인에서 장병들의 관심이 식판 및 수저보다 식탁과 바닥의 청결 상태라는 점은 현재 군 단체 급식 시설에서 식탁 관리와 바닥의 청결 상태에 대한 장병들의 민감도가 높다고 인식된다. 급식 환 경 면에서는 식당 내부 인테리어, 편안한 조명 및 분위기, TV 및 오디오 등 편의시설의 적절한 배 치, 내부 공간 이용의 편리성 순으로 요인적재값이 높았다. 이는 장병들이 입대 전 외식 전문업체나 학교, 산업체 단체급식 시설과 비교 시 군 단체급식 시설에서 환경 면의 차이가 반영된 결과로 분 석된다. 끝으로 급식 운영은 식사에 대한 영양 정보 제공, 공지된 식단표 준수, 적정한 식사시간 보 장, 주기적인 메뉴 순환, 배식 시 지체 방지, 취사장 요원들의 친절성 등이 요인적재값이 높아 건강 하고 여유있는 식사가 중요한 요인으로 인식되고 있었다.

둘째, 외생변수인 급식 서비스 품질 요인과 내생변수인 급식만족도 및 무형전투력의 모형적합도 와 집중 타당도, 판별 타당도 검증을 실시하였다. 이를 통하여 급식 서비스 품질 관리를 위한 하위 요소들을 식별하였다. 외생변수인 급식 서비스 품질 요인은 29개 항목을 측정하였다. 이중 관측변수 들의 일치성을 평가하는 집중 타당성, 탐색적 요인분석 및 신뢰도 분석을 실시하였다. 급식 운영 요 인에서 취사 요원들의 친절성에 관한 문항 등 7 개 문항이 삭제되고 22 개 문항이 적용되었다. 내생변 수인 급식 만족도와 무형전투력에서는 12 개의 문항을 모형적합도 기준을 충족하기 위한 수정지수로 사용하여 삭제함으로써 집중 타당성과 판별 타당성을 확보하였다. 이로써 급식 품질서비스 요인은 급식 위생, 급식 질, 급식 환경, 급식 운영 4개 요인 22개 문항으로 정리되었다. 급식 만족도 및 무형 전투력과 관련하여 만족도는 음식 질, 위생, 환경, 운영, 전반적인 만족 등 5 개 문항, 무형전투력은 급식 질과 단결력, 급식 위생과 사기 및 규정 준수, 급식 환경은 훈련 의지, 사기, 급식 운영은 사기와 규정 준수, 급식 만족도는 단결력 등 8개 문항에서 유의한 결과를 나타내는 것으로 식별되었다.

셋째, 정규성 검증 및 연구 변인 특성 분석과 상관관계 분석을 통하여 급식 서비스 품질 요인들 이 급식 만족도 및 무형전투력에 미치는 영향을 식별하였다. 이번 연구를 통하여 확인된 장병들의 급식 서비스 품질 요인에 대한 만족도는 급식의 질 평균 3.21점, 급식 위생 평균 3.54점, 급식 환경 평 균 3.35점, 급식 운영 평균 3.70점으로 나타났다. 급식의 질에 대한 만족도가 가장 낮으며 급식 운영에 대한 만족도가 가장 높았다. 따라서 향후 군 단체급식 서비스 품질 향상을 위해서는 급식의 질적인 면 
에서 장병들의 욕구 충족을 위한 요소가 무엇인지를 식별하고 이제 대한 조치가 중요할 것으로 식별 되었다. 음식 질에서 장병들이 고려하는 중요 요인은 맛, 간, 품질이 우수한 식사 재료, 메뉴의 다양성, 식사량, 건강식 메뉴로 식별되었다. 급식 서비스 품질 요인과 급식 만족도에 대한 상관관계 지수는 급 식의 질 .820, 급식 위생 .758, 급식 환경 .758, 급식 운영 .724로 나타났다. 따라서 급식 만족도 향상을 위해서는 급식의 질 향상이 가장 중요하며 급식 위생과 환경, 급식 운영면에도 상관관계 지수가 매우 높게 식별되어 급식 만족도 향상을 위해서는 종합적인 관리가 필요할 것으로 판단된다.

장병들의 사기 진작과 단결력, 훈련 의지, 규정 준수에 대한 의지는 행동과 태도로 나타난다. 이 러한 행동가 태도가 행태적 무형전투력이다. 급식 서비스 품질 요인과 무형전투력과의 상관관계 지 수는 급식의 질 .223, 급식 위생 .281, 급식 환경 .240, 급식 운영 .308, 급식 만족 .261로 지수가 높게 나오지는 않았다. 그러나 무형전투력을 향상시키는 데는 급식의 질보다 친절하고 효과적인 급식 운 영, 깨끗하고 청결한 급식 위생, 편리하고 쾌적한 급식 환경 요인이 더 상관관계가 높다는 점을 인 식할 필요가 있다. 이제 장병들은 밥 한 끼 잘 먹었다고 열심히 훈련을 받아야지 하는 것이 아니라 친절하고 위생적이며 깨끗하고 쾌적한 환경에서 맛있는 식사를 하는 여건이 보장될 때 행태적 무 형전투력도 향상될 수 있을 것으로 본다.

\section{VI. 결론 및 제언}

이번 연구 결과를 통한 군 단체급식 정책 방향에 대한 시사점을 요약하면 다음과 같다.

첫째, 군 단체급식 서비스 품질 관리는 급식 질, 위생, 환경, 급식 운영의 4 가지 영역에 대하여 장병 복무 의욕 증진과 무형전투력 향상을 위한 전략적인 수준에서 관리가 필요하다. 본 연구에서 장병들은 음식은 맛이 가장 중요하면서도 서비스 품질 관리 요인 중 급식 위생과 환경, 급식 운영 면에도 민감도가 높았다. 따라서 이제 군 단체급식 서비스 품질 향상은 위생과 환경, 운영을 포함하 는 포괄적 차원에서 관리하는 지혜가 필요하다.

둘째, 단체급식 전문 업체 및 기술 활용에 대한 검토가 필요하다. 입대 전 장병들은 다양하고 수 준 높은 단체급식 서비스 품질을 경험하고 입대하였다. 그리고 군 급식 서비스 품질에 대한 만족도 는 높지 않다. 이를 해소하기 위하여 군에서는 매년 급식비를 인상하여 신메뉴 개발과 다양한 후식 지원, 시설 현대화, 취사 요원 조리 교육을 강화하고 있다. 하지만 전문 식품 연구기관을 가지고 단 체급식을 전담하여 메뉴 개발 및 조리, 공급체계를 유지하는 외부 기관의 발전 속도를 따라 잡지 못하고 있다. 따라서 이제는 군 단체급식을 군에서 전담한다는 인식에서 탈피하여 민간 전문기술과 조직을 활용한다는 인식으로 접근할 필요가 있다.

셋째, 1 식 4찬의 표준 식단을 뷔페식으로 조정을 검토할 필요가 있다. 군은 그동안 신세대 장병 들의 입맛 변화를 고려하여 주식(쌀) 소비량을 줄이고, 장병들 선호도가 높은 분식(떡국, 스파게티, 
쫄면 등)과 같은 양질의 부 - 후식을 제공해 왔다. 그럼에도 이번 연구결과, 급식 서비스 품질 요인 중 급식의 질에서 장병들은 식사량의 적절성과 메뉴의 다양성에 대하여 부정적인 의견이 가장 많 이 나타났다. 이런 결과를 토대로 장병들이 각자의 음식 선호도와 일일 활동을 고려하여 선택적으 로 급식을 할 수 있도록 뷔페식으로 식단을 조정할 필요성이 있다고 볼 수 있다.

넷째, 급식 시설과 환경개선 및 관리를 위한 전문가 및 조직 운영이 필요하다. 장병들의 급식 만 족도는 이제 음식의 질에 국한되는 것이 아니다. 서비스 품질 요인 중 급식 환경과 운영에도 많은 영향을 받고 있었다. 군은 취사 단위 부대별로 급양 관리관과 조리 부사관을 운영하며 시설 및 환 경개선을 위해 노력하고 있다. 그러나 최근 외부 기업의 단체급식 시설이나 환경과 비교하면 전문 성과 운영 능력 면에서 점점 차이가 발생하고 있다. 따라서 군의 단체급식 시설 및 환경개선도 군 에서만 전담할 것이 아니다. 군과 민간 전문가를 통합적으로 운영하여 미흡한 점을 개선하고 수준 을 향상시켜 관리할 필요가 있다.

다섯째, 급양 관계관 교육 및 조리병 운영체계에 대한 개선이 필요하다. 모든 일의 주체는 사람 이다. 군의 인적 구성과 보직 순환 주기를 고려할 때 군 단체 급식장의 전문성은 민간 급식장에 비 교하면 많이 부족하다. 조리병들의 $47.6 \%$ 는 입대 전에 조리 관련 경험이 없는 상태에서 군 입대 후 조리병 특기를 받고, 이 중 $24.7 \%$ 는 조리병 교육을 받지 않고 매끼 수백명이 식사를 하는 군 단체 급식장에서 조리를 담당하고 있다. 또한, 18 개월이라는 조리병들의 복무 개월을 고려하면 군 급식은 우수한 식재료가 보급된다고 하더라도 음식의 손맛을 내는 것은 한계가 있다. 이번 연구에 서 군 식사 재료의 품질이 우수하다고 답변한 인원은 $37.8 \%$ 였으나 맛이 좋다고 답변한 인원은 $33.5 \%$ 의 수준을 보였다.

여섯째, 국민 건강관리 및 식사문화 개선 차원에서 군 급식 관리 필요성 검토가 필요하다. 군 단 체급식은 민간 급식과 달리 일일 3끼 식사와 후식, 증식 등 장병들이 먹는 모든 식사를 제공하고 있다. 따라서 장병들은 복무 기간 중 영양과 건강관리를 부대 급식에 의존하고 있다. 민간 단체급식 은 급식 대상자의 성장주기와 직무를 고려하여 국민건강관리 차원에서 관리되고 있다. 단체 급식은 급식과 연계하여 영양 관리와 식생활 교육이 병행될 수 있는 장점을 갖고 있다. 따라서 군 단체급 식은 국민건강관리공단과 대한영양사협회 등 전문기관의 협조를 받아 식단 구성과 식생활 교육 등 이 전문적으로 진행될 필요가 있다고 본다.

\section{Acknowledgements}

We would like to thank Editage (www.editage.co.kr) for English language editing.

\section{Declaration of Conflicting Interests}

The author(s) declared no potential conflicts of interest with respect to the research, authorship, and/or publication of this article. 
The effect of the quality of the military's feeding system on meal service satisfaction ... / Sangho Lee 87

\section{Reference}

Allen, J. P., \& Bell, D. B. (1980). Correlates of Military Satisfaction and Attrition among Army Personnel. https://doi.org/10.21236/ada109456

BRADY, M., KNIGHT, G., CRONINJR, J., TOMAS, G., HUlT, M., \& KEILlOR, B. (2005). Removing the contextual lens: A multinational, multi-setting comparison of service evaluation models. Journal of Retailing, 81(3), 215-230. https://doi.org/10.1016/j.jretai.2005.07.005

Choi, D., \& Lee, I. (2012). Satisfaction of Foodservice and Eating Behavior of Male Military Personnel in Backryung-do. The East Asian Society of Dietary Life, 22(5), 576-584. UCI : G704-001333.2012.22.5.007

Cronin, J. J., \& Taylor, S. A. (1992). Measuring Service Quality: A Reexamination and Extension. Journal of Marketing. 56(3), 55-68. https://doi.org/10.2307/1252296

Han, H. (2007). Study on Influence of Quality of Catering Service on Customer Satisfaction and Customer Loyalty: Focused on the customers of catering service at the universities located in Seoul, Korea. Master Dissertation, Chodang University.

Jeon, J., \& Park, J. (2015). Major Issues and Direction of Combat Level Evaluation. Defense Issues \& Analyses, 1581, 1-8. https://www.kida.re.kr/frt/board/frtNormalBoardDetail .do? $\operatorname{sidx}=382 \&$ idx $=1631 \&$ depth $=3 \&$ lang $=\mathrm{kr}$

Kim, H., Kim, Y., \& Cha, S. (2012). Impact of Industrial Catering Food Service Factors on Foreign Workers' Satisfaction in Ansan City. Journal of Tourism Sciences, 36(3), 277-293. UCI : G704-000001.2012.36.3.014

Kim, Y., \& Park, J. (2020). The Study on the Recognition of Important Degree by Intangible Combat Power Components. Journal of Advances in Military Studies, 3(1), 75-92. https://doi.org/10.37944/jams.v3i1.68

Kim. G. (2017). Latent Growth Modeling and Structural Equation Modeling analysis (AMOS, LISREL). Hannarae Publishing: Seoul. ISBN : 9788955660944(8955660944

Koo, J., \& Park, Mi. (2012). Leadership Effectiveness Level and Fighting Spirit: Focusing on the case of Band of Bothers. KIDA Defense Weekly, 1424, 1-12. https://www.google.com/url?sa=t\&rct=j\&q=\&esrc=s\&source=web\&cd=\&ved=2ahUKEwiH 7JWnid7tAhXWMd4KHf8YD5cQFjAAegQIAxAC\&url=http\%3A\%2F\%2Fwww.kida.re.kr \%2Fcmm\%2FviewBoardImageFile.do\%3Fidx\%3D13300\&usg=AOvVaw3zQe0P5krchbrLn 


\section{O5PU0X5}

Lee, D., Bae, B. Y., \& Choi, S. (2020). An Empirical Study on the Effect of Military Foodservice Satisfaction on Soldiers' Morale. Journal of Society of Korea Industrial and Systems Engineering, 43(3), 228 - 242. https://doi.org/10.11627/jkise.2020.43.3.228

Lee, S. (2012). The Effects of Servicescape on Customer Behavior. Seoul: Kyoungki University, Doctor Dissertation.

Oliver, R. L. (1997). Satisfaction: A behavioral perspective on the consumer. Boston, Mass: Irwin/McGraw-Hill.

Park, M. (2016). A study on the Effects of satisfied with meal service quality of meals, Nursing Homes : Focused on the Busan Regional. Busan: Nambu University. Master Dissertation. Park, S. (2015). The Effects of School Feeding Service Quality on Students' Practice and Satisfaction of School Feeding - Focusing on High School Students in Daegu. International Journal of Tourism Management and Sciences, 29(6), 69-82. UCI : G704-000941.2015.29.6.012

김대희(2018). 한끼 5천원이면 구글 애플같은 급식. 미래경제 신문, 2018.11.15. http://www.mirae-biz.com/news/articleView.html?idxno=42730

이의경(2017). 급식도 고급스럽게...호텔 빰치는 구내식. 대한급식신문, 2017.4.6. http://www.fsnews.co.kr/ news/articleView.html?idxno=20557

이종현, 김환정, 문광건(2001). 무형전력평가체계 기반연구: 전투요원의 행태적 측면을 중심으로. 한국국 방연구원, 104-113. http://www.prism.go.kr/homepage/researchCommon/downloadResearch AttachFile.do;jsessionid=3E3F527349015757F99DAEDED50C438C.node02?work_key=001\&file_ type=CPR\&seq_no=001\&pdf_conv_yn=Y\&research_id=1290000-200100011 


\section{군 단체급식 서비스 품질이 급식 만족도 및 무형전투력에 미치는 영향 연구: 병사의 행태적 무형전투력을 중심으로}

이상호*

본 연구는 군 단체급식 서비스 품질이 급식 만족도 및 무형전투력에 미치는 영향을 분석하였다. 연구 결과 는 군 급식정책과 예산을 효율적으로 운영하기 위한 정책적 시사점을 제공할 것이다.

군 단체급식 서비스 품질 요인은 급식 질, 위생, 환경, 운영 등 4 개 요인으로 식별되었다. 장병들의 급식 서 비스 품질 만족도는 급식 질 3.21점, 급식 위생 3.54점, 급식 환경 3.35점, 급식 운영 3.70점으로 확인되었다. 급식 질에 대한 만족도가 가장 낮은 것으로 나타났다. 급식 서비스 품질과 급식 만족도의 상관관계 지수는 급 식 질 .820, 급식 위생 .758, 급식 환경 .758, 급식 운영 .724로 나타났다. 급식 만족도 향상을 위해서는 급식 질 뿐만 아니라 위생과 환경, 운영 면에도 관심이 요구되었다. 급식 서비스 품질과 무형전투력과의 상관관계 지수는 급식 질 .233, 급식 위생 .281, 급식 환경 .240, 급식 운영 .308로 확인되었다. 상관관계 지수가 높지는 않으나 유의한 영향을 미치는 것으로 나타났다.

따라서 향후 군 단체급식 서비스 품질 관리는 급식 질 뿐만 아니라 위생, 환경, 운영 면에 균형된 감각을 가지고 관리가 필요한 것으로 확인되었다. 행태적 무형전투력 향상을 위해서는 급식 질보다 운영과 위생, 환 경 면에서 상관관계 지수가 높다는 것을 유의할 필요가 있는 것으로 나타났다.

주제어 : 군 단체급식, 서비스 품질, 서비스 만족도, 무형전투력

* (제1저자) 광운대학교 방위사업학과 박사과정 (육군종합군수학교, 학교장) 
